\title{
Nitrogen and Phosphorous Removal in Municipal Wastewater Treatment Plants in China: A Review
}

\author{
Yong Qiu, ${ }^{1}$ Han-chang Shi, ${ }^{1,2}$ and Miao He ${ }^{1}$ \\ ${ }^{1}$ Department of Environmental Science and Engineering, Tsinghua University, Beijing 100084, China \\ ${ }^{2}$ State-key Joint Laboratory of Environmental Simulation and Pollution Control, Beijing 100084, China \\ Correspondence should be addressed to Han-chang Shi, hanchang@tsinghua.edu.cn
}

Received 15 January 2010; Revised 12 April 2010; Accepted 26 April 2010

Academic Editor: Josiane Nikiema

Copyright (C) 2010 Yong Qiu et al. This is an open access article distributed under the Creative Commons Attribution License, which permits unrestricted use, distribution, and reproduction in any medium, provided the original work is properly cited.

\begin{abstract}
Surface water environment in China was degraded rapidly in the last two decades, resulting in increasingly tighten criteria issued for municipal wastewater treatment plants (WWTPs). This paper reviewed the recent advances of process design and operational optimization for nutrients removal. Three major processes, as anaerobic-anoxic-oxic (AAO) process, oxidation ditch (OD), and sequencing batch reactor (SBR) occupied 65\% of WWTPs amounts and 54\% of treatment volumes of China in 2006 . However conservative process designs and operational faults often impaired the process performances and energy efficiency. Therefore, typical processes were modified, combined, and innovated to meet the requirements of the diverse influent characteristics and lower energy consumptions. Furthermore, operational optimization techniques by modeling, simulation, and real-time control were also developed and applied in China to improve the process operation. Although great efforts had been contributed to improve the WWTPs performances in China, attentions should be continuously paid to the introduction, instruction, and implementation of advanced techniques. At last, the technical demands and appropriated techniques of WWTPs in China were briefly discussed.
\end{abstract}

\section{Introduction}

In the last two decades, surface water environment in China was rapidly degraded by the booming industrialization and fast urbanization. The first large scale municipal wastewater treatment plant (WWTP) in China was constructed and operated 25 years ago [1]. In recent ten years, the construction of municipal WWTPs was catalyzed by the serious deterioration of surface water around cities, as shown in Figure 1. The reduction of ammonia nitrogen $\left(\mathrm{NH}_{3}-\mathrm{N}\right)$ and total phosphorous (TP) are also shown in the figure [2] in the unit of part per million ( $\mathrm{ppm}$ ) and also $\mathrm{mg} / \mathrm{L}$ in water. The ammonia reduction was only 13.2 to $18.3 \mathrm{mgN} / \mathrm{L}$ and the phosphorous reduction was almost constant at $2.5 \mathrm{mgP} / \mathrm{L}$ from 2001 to 2007 [1], implying unsatisfied process performances in current WWTPs.

The rapid development of municipal WWTPs and their unsatisfied performances promoted the engineering innovations, as well as the academic studies. In this paper, the recent progresses of nitrogen and phosphorous removal in municipal WWTPs were reviewed in the aspects of process design and operational optimization, the advances in academic studies, and the practices in engineering fields in China.

\section{WWTP Processes in China}

\subsection{Features of Processes in WWTPs in China}

2.1.1. Composition of WWTPs Processes. Biological nutrients removal (BNR) processes apply alternative aerated and unaerated environments to remove nitrogen and phosphorous from water by the growth and metabolism of specific bacteria. Typical BNR processes include conventional activated sludge (CAS) process, anaerobic-anoxic-oxic (AAO) process, anaerobic/anoxic-oxic (AO) process, oxidation ditch (OD), sequencing batch reactor (SBR), membrane bioreactor (MBR), biofilm reactor, and lagoon [3].

Figure 2 shows the WWTPs amounts and the treatment wastewater volumes for BNR processes in China in 2006. The statistic data covered $74 \%$ and $77 \%$ of the total ranges of 


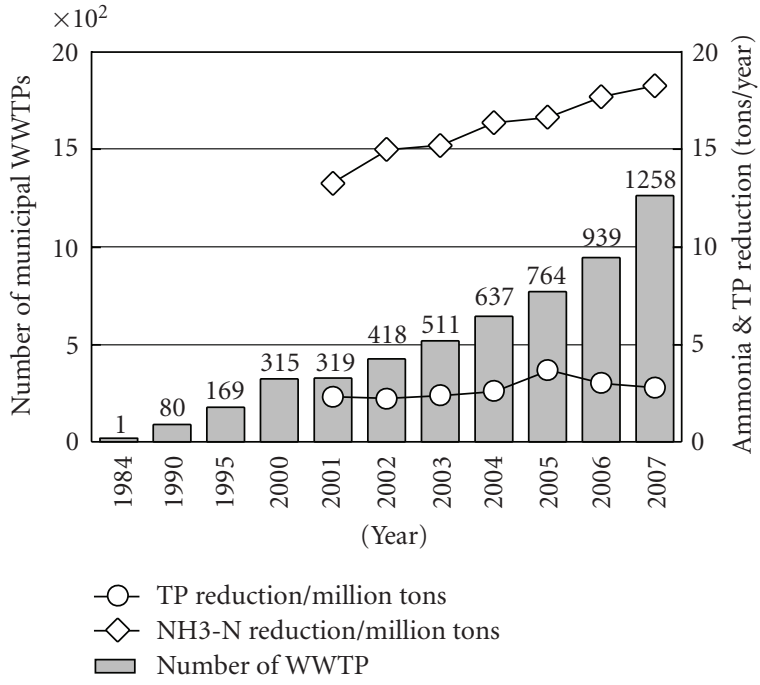

FIgURE 1: Nutrients reduction in municipal WWTPs based on treated wastewater in China.

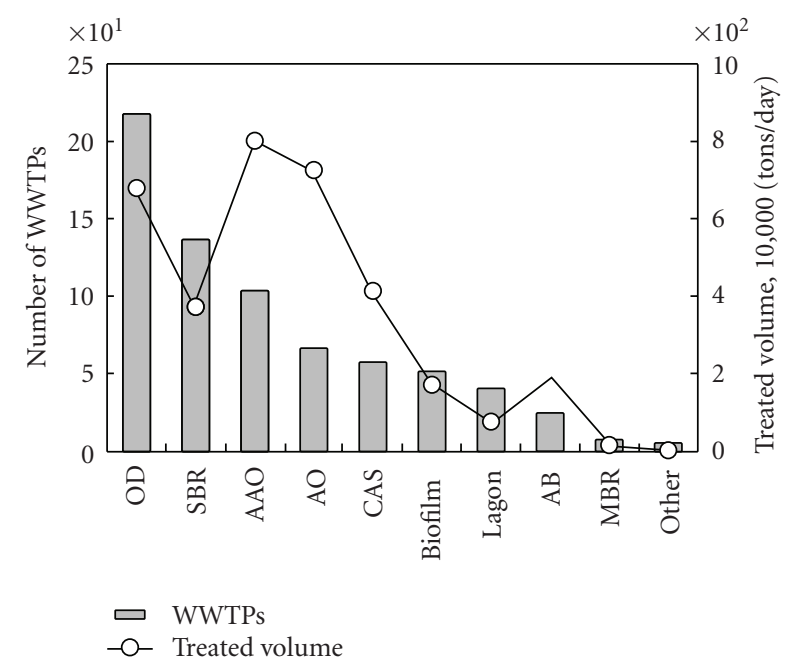

FIGURE 2: Composition of processes in municipal WWTPs in China.

TABLE 1: Capacities of WWTP processes in geographic zones of China in $2006^{\mathrm{a}}$.

\begin{tabular}{|c|c|c|c|c|c|c|c|}
\hline & North & East & Northeast & Middle & South & Southwest & Northwest \\
\hline OD & 110 & 280 & 0 & 140 & 40 & 60 & 50 \\
\hline SBR & 30 & 120 & 70 & 10 & 50 & 80 & 30 \\
\hline $\mathrm{AAO}$ & 220 & 370 & 10 & 20 & 120 & 60 & 20 \\
\hline $\mathrm{AO}$ & 120 & 290 & 120 & 110 & 40 & 60 & 1 \\
\hline $\mathrm{CAS}^{\mathrm{b}}$ & 60 & 110 & 50 & 50 & 130 & 10 & 10 \\
\hline
\end{tabular}

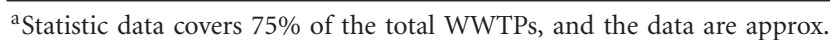
total capacities for each process. Capacity is in the unit of 10,000 tons/day;

${ }^{\mathrm{b}}$ Conventional activated sludge processes including primary treatment processes.

WWTPs amounts and treated volumes, respectively. Among the investigated processes, OD, SBR, and AAO were the three major processes, which together occupied $65 \%$ of WWTPs amounts and 54\% of treated volumes. The different occupations among the investigated processes were related with their distinct features, for example, easiness of operation and maintenance, instrumental requirements, and energy consumptions, and also of great importance, related with the process reformation and upgrade. It could be expected that WWTPs numbers and treated wastewater volumes of AAO process would be continuously increased by the strong potential of the reformation of CAS process.

2.1.2. Spatial Distributions of WWTPs Processes. Table 1 shows the spatial distributions of the major processes in the seven geographic zones of China. The amounts of wastewater were usually determined by the population densities and economic levels, therefore larger volumes of wastewater were treated in the North, South, and East China than other zones. The process design of WWTPs was often affected by comprehensive factors in China, such as distinct features of different processes, natural conditions like temperature and water resources, social situations like population and economics, and the orientations of process designers. For example, OD process has never been applied in the Northeast China because of the very low ambient temperature there. However, it was popularly adapted in the East and Middle China because of the less production of excessive sludge and the designers' favorites.

2.1.3. Performances of WWTPs Processes. Table 2 shows the different performances of the major processes in 2006, including the influent concentrations and average removal rates of pollutants. The major processes showed similar performances on the removal of $\mathrm{COD}, \mathrm{NH}_{3}-\mathrm{N}, \mathrm{TN}$, and TP according to the table. The better performance of phosphorous removal over nitrogen removal was partially related with the chemical precipitation processes optionally adapted in municipal WWTPs.

2.2. Developing Criteria for Nutrient Removal. Table 3 lists the historical discharging standards for municipal WWTPs in China, which reflects the development trace of municipal wastewater treatment [1]. Only the criteria of nutrients were shown in the table because the complete contents were too much to be included. According to the table, $\mathrm{NH}_{3}-\mathrm{N}$ and TP were firstly included in the national criteria in 1998 and TN was additionally included in 2003. During the process reformations and upgrades, current active $I-A$ level became the ambition of municipal WWTPs because it was the limits to WWTP effluents for water reuse and recycling. At the areas with serious pollution of surface water, for example, around Taihu Lake, more tightened criteria than national $I-A$ level were issued to control the eutrophication. The criteria in the future were expected to be close to the surface water quality standards, as shown in the table, to meet the requirements of wastewater reclamation due to the crisis of water shortage in municipal cities.

2.3. Difficulties for Successful BNR Processes. Performances of BNR processes were often impaired by the improper design and operation, which often occurred in municipal WWTPs 
TABLE 2: Performance of major WWTP processes in China in 2006 (unit, mg/L).

\begin{tabular}{|c|c|c|c|c|c|c|c|c|c|c|c|c|}
\hline & mean $^{\mathrm{a}}$ & $\begin{array}{l}\text { COD } \\
\text { range }^{b}\end{array}$ & $\%^{c}$ & mean $^{\mathrm{a}}$ & $\begin{array}{r}\mathrm{NH}_{3}-\mathrm{N} \\
\text { range }^{\mathrm{b}}\end{array}$ & $\%^{c}$ & mean $^{\mathrm{a}}$ & $\begin{array}{l}\mathrm{TN} \\
\text { range }^{\mathrm{b}}\end{array}$ & $\%^{c}$ & mean $^{a}$ & $\begin{array}{l}\mathrm{TP} \\
\text { range }^{\mathrm{b}}\end{array}$ & $\%^{c}$ \\
\hline OD & 320 & $125-550$ & $84 \%$ & 28 & $12-46$ & $68 \%$ & 34 & $18-58$ & $59 \%$ & 4.2 & $1.2-7$ & $71 \%$ \\
\hline SBR & 300 & $120-500$ & $83 \%$ & 27 & $10-48$ & $66 \%$ & 34 & $15-57$ & $58 \%$ & 4.0 & $1.2-6$ & $71 \%$ \\
\hline $\mathrm{AAO}$ & 390 & $150-700$ & $85 \%$ & 32 & $14-54$ & $75 \%$ & 39 & $16-68$ & $55 \%$ & 5.4 & $2.0-10$ & $78 \%$ \\
\hline $\mathrm{AO}$ & 460 & $140-860$ & $80 \%$ & 31 & $11-49$ & $64 \%$ & 46 & $19-74$ & $58 \%$ & 5.3 & $1.0-9$ & $70 \%$ \\
\hline CAS $^{\mathrm{d}}$ & 440 & $175-790$ & $88 \%$ & 34 & $14-58$ & $50 \%$ & 40 & $6-86$ & $42 \%$ & 4.9 & $1.7-10$ & $66 \%$ \\
\hline
\end{tabular}

${ }^{\mathrm{a}}$ Average concentrations of pollutants in raw influent to WWTPs; ${ }^{\mathrm{b}} 10$ and 90 percentiles in the distribution of pollutant concentrations; ${ }^{\mathrm{c}}$ Removal rates based on average values of WWTP influent and effluent; ${ }^{\mathrm{d}}$ Conventional activated sludge processes with primary and secondary treatment.

TABLE 3: National discharge criteria of municipal WWTPs in China.

\begin{tabular}{|c|c|c|c|c|c|c|c|c|}
\hline Standards & Levels & $\mathrm{COD}_{\mathrm{Cr}}$ & $\mathrm{BOD}_{5}$ & SS & $\mathrm{NH}_{3}-\mathrm{N}$ & $\mathrm{TP}$ & $\mathrm{TN}$ & Active time \\
\hline GB-73 & & 100 & 60 & 500 & & & & 1973 \\
\hline GB8978-88 & & 120 & 30 & 30 & & & & 1989.1.1 \\
\hline \multirow[t]{2}{*}{ GB8978-96 } & II level & 120 & 30 & 30 & 15 & 1 & & 1998.1.1 \\
\hline & I level & 60 & 20 & 20 & 15 & 0.5 & & \\
\hline \multirow[t]{3}{*}{ GB18918-2002 } & II level & 100 & 30 & 30 & $25(30)^{\mathrm{a}}$ & 3 & & 2003.1.1 \\
\hline & I-B level & 60 & 20 & 20 & $8(15)$ & 1 & 20 & \\
\hline & I-A level & 50 & 10 & 10 & $5(8)$ & 0.5 & 15 & \\
\hline Expectation & & $20^{\mathrm{b}}$ & 3 & 3 & 1 & $0.1^{\mathrm{c}}$ & 5 & future \\
\hline
\end{tabular}

${ }^{\mathrm{a}}$ Criteria for chilly weather lower than 12 Celsus degree; ${ }^{\mathrm{b}} \mathrm{COD}_{\mathrm{Mn}}$ in surface water instead of $\mathrm{COD}_{\mathrm{Cr}}$ in wastewater; ${ }^{\mathrm{c}}$ Standards only for lake water and reservoirs.

in China. Typical problems in process design and operation were usually derived from diverse influent characteristics, inevitable design defects, and undeveloped operation levels.

2.3.1. Inadequate Studies on Influent Characteristics. The design and operation of WWTP processes in China were based on experiences of engineers rather than scientific conclusion. There are very few investigations on the components in the influent of municipal WWTPs, as well as the spatial and seasonal variations of influent concentrations in China, resulting in inadequate knowledge on the diverse influent characteristics. The studies on influent characterization were affected by the greatly varied natural and social conditions all over the country, for example, developing industries and constructing sewer systems may intensively change the influent components in short period. Furthermore, the difficulties of continuous monitoring, the lack of data accumulation, and the negative wills of managers in WWTPs hindered the optimization of BNR processes.

2.3.2. Defects in Process Designs. Process designers in China often followed the similar influent characteristics to start the design without careful investigations on the actual concentrations of pollutants. Except of the uncertainty of influent characteristics, process designers might face more complicated situations like the absence of sewer system data, inaccurate prediction of population, uncontrolled industrial wastewater discharge, and so forth, limiting their possibility to design the configuration with satisfied flexibility. Therefore big variation coefficients, large volumes of tanks, and very long hydraulic retention times were utilized in the designs to ensure the security of process operation. This situation produced conservative and rigid processes and resulted in operational difficulties, for example, very few designs allowed engineers to change the return flows of mixed liquor along with the influent flows.

2.3.3. Undeveloped ICA Levels. The WWTPs were almost tripled in the last seven years as shown in Figure 1, requesting not only the huge amount of infrastructural investments but also a number of skilled and experienced operational engineers which could not be cultured in short time. Instrumentation, control, and automation (ICA) techniques could alleviate this human resource crisis, which had been developed and successfully applied in municipal WWTPs in Europe [4]. In this field, the researchers in China made rapid progresses in the theoretical studies, control algorithms, optimization strategies, and supervisory systems. However, the application of ICA techniques in actual processes was still very limited due to the expensive online instruments and the current huge amount of employees.

\section{Advances in Process Design and Innovation}

\subsection{Process Design and Augmentation}

3.1.1. Process Design for Municipal WWTPs. After 25 years of practices on large-scale municipal WWTPs, the process design has been gradually improved in China. Table 4 shows the processes and performances of several example 
TABLE 4: Typical processes applied in municipal WWTPs and their performances in 2006.

\begin{tabular}{|c|c|c|c|c|c|c|c|c|}
\hline \multirow[t]{2}{*}{ Group } & \multirow[t]{2}{*}{ Process } & \multirow[t]{2}{*}{ WWTPs } & \multirow[t]{2}{*}{ From $^{\mathrm{m}}$} & \multirow{2}{*}{$\begin{array}{l}\text { Capacity } \\
10^{4} \mathrm{~m}^{3} / \mathrm{d}\end{array}$} & \multicolumn{4}{|c|}{ Removal by WWTP, $\%^{\mathrm{n}}$} \\
\hline & & & & & COD & $\mathrm{NH}_{3}-\mathrm{N}$ & $\mathrm{TN}$ & TP \\
\hline \multirow{5}{*}{$\mathrm{AAO}$} & $\mathrm{r}-\mathrm{AAO}^{\mathrm{a}}$ & Gaobeidian in Beijing & 1993 & 100 & 90 & 90 & 50 & 20 \\
\hline & AAO & Xiaohongmen in Beijing & 2005 & 60 & 90 & 90 & 60 & 60 \\
\hline & $\mathrm{AO}$ & Jizhuangzi in Tianjin & 2005 & 54 & 90 & 70 & 55 & 90 \\
\hline & $\mathrm{A}-\mathrm{AAO}^{\mathrm{b}}$ & Tangjiatuo in Chonging & 2006 & 30 & 85 & 85 & 60 & 50 \\
\hline & $\mathrm{VIP}^{\mathrm{c}}$ & Licunhe in Qingdao & 1998 & 8 & 95 & 90 & & 80 \\
\hline \multirow{4}{*}{ SBR } & CAST $^{d}$ & Zhengrun in Zhenjiang & 2003 & 10 & 80 & 20 & 10 & 90 \\
\hline & DAT-IAT $^{\mathrm{e}}$ & Diyi in Benxi & 2004 & 23 & 70 & 80 & 50 & 70 \\
\hline & UNITANK $^{\mathrm{f}}$ & Chengbei in Nanjing & 2003 & 30 & 80 & 75 & 55 & 80 \\
\hline & ICEAS ${ }^{\mathrm{g}}$ & Disan in Kunming & 1997 & 15 & 80 & 80 & 40 & 55 \\
\hline \multirow{5}{*}{ OD } & Orbal & Chengbei in Wuxi & 2001 & 10 & 90 & 90 & & 90 \\
\hline & Carrousel & Yangli in Fuzhou & 2003 & 20 & 85 & 90 & 40 & 55 \\
\hline & $\mathrm{T}-\mathrm{OD} \mathrm{D}^{\mathrm{h}}$ & Luofang in Shenzhen & 2001 & 25 & 90 & 85 & & 60 \\
\hline & DE-OD ${ }^{\mathrm{i}}$ & Beishiqiao in Xi'an & 1998 & 15 & 95 & 90 & 70 & 90 \\
\hline & $\mathrm{A}+\mathrm{OD}^{\mathrm{j}}$ & Dongjiang in Dongguan & 2002 & 20 & 90 & 90 & & 50 \\
\hline \multirow{2}{*}{ Biofilm } & $\mathrm{BAF}^{\mathrm{k}}$ & Xiannvhe in Shenyang & 2003 & 40 & 85 & 35 & & 85 \\
\hline & BioLak $^{1}$ & Binzhoushi in Shandong & 2002 & 10 & 80 & 70 & & 50 \\
\hline
\end{tabular}

a reverse AAO; ${ }^{\mathrm{b}} \mathrm{AAO}$ with preanoxic zone; ${ }^{\mathrm{c}}$ VIP process; ${ }^{\mathrm{d}}$ Cyclic activated sludge technology; ${ }^{\mathrm{e}}$ UNITANK process; ${ }^{\mathrm{f}}$ Demand aeration tank-intermittent tank; ${ }^{g}$ Intermittent cycle extended aeration; ${ }^{h}$ Triple channel oxidation ditch; ${ }^{i}$ Dual channel oxidation ditch; ${ }^{j}$ Anaerobic zone before Carrousel oxidation ditch; ${ }^{k}$ Biological aeration filter; ${ }^{l}$ BioLak is a process developed by a German Company; ${ }^{\mathrm{m}}$ The time of operation started; ${ }^{\mathrm{n}}$ Removal rates calculated approximately by values in 2006 .

WWTPs in 2006 [3]. AAO process group in China usually included conventional $\mathrm{AAO}$, reverse $\mathrm{AAO}, \mathrm{AO}, \mathrm{AAO}$ with preanoxic zone (A-AAO), and UCT/VIP processes. SBR process group consisted of CAST, DAT-IAT, UNITANK, and ICEAS processes. OD process groups adapted in China were Orbal, Carrousel, T-OD, DE-OD, and other modifications like Carrousel with preanaerobic zones (A+OD) [5].

The scheme diagrams of above processes were shown in Figure 3. The more candidate processes gave designers more possibilities to configure good processes with lower cost and higher efficiency. For example, in order to deal with the distinct conflicts between nitrogen removal and phosphorous removal in AAO process, designers may adapt reverse AAO ( $\mathrm{r}-\mathrm{AAO})$ or A-AAO process to enhance the nitrogen removal with the price of unsatisfied phosphorous reduction [6], and other designers may prefer simple AO process coupled with chemical precipitation. Furthermore, decision-making tools for complicated multicriteria, such as capital and operation cost, land area, nutrient removal, and sludge disposal, were developed to obtain scientific and reasonable process among municipal wastewater treatment alternatives [7].

Local enterprises in China had integrated or modified the imported processes in their engineering practices as shown in Figure 4, such as CSBR (continuous flow/constant level SBR) modified by THUNIP Company, DF-MBR (dual filtration membrane bioreactor) integrated by NEPRI (national electricity environmental protection institute of China), modified Carrousel OD developed by Anhui Guozhen Corp., and HSCBR (high efficient separation composite biological fluidized reactor) owned by Jiangsu Yihuan Corp [8].
3.1.2. BNR Augmentation Attempts. Bioaugmentation was often applied to enhance the nutrients removal in conventional processes in China. The most popular solution was to introduce specially designed porous media into the aeration tanks to augment biofilm reactions [9]. The total biomass concentrations could be augmented from $3.2 \mathrm{~g} / \mathrm{L}$ to $4.3-5.8 \mathrm{~g} / \mathrm{L}$ with the carriers in $15 \%-30 \%$ of volumetric portion [10]. The media characteristics of surface areas and hydrophobic properties were important for the performance of biofilm and its startup.

In South China, domestic wastewater is always low in strength due to the high water level of groundwater and setting of septic tank at the beginning of wastewater collection system [6]. The bioaugment process, which installed polyurethane foams as carriers and inoculated specialized bacteria on the media, was found more easily started up in lower DO concentrations [11]. Zeolite was also used to enhance conventional contact stabilization activated sludge process and improved nitrogen removal for $27 \%$, by the mechanism of preferential ion exchange of zeolite to ammonium [12].

3.2. Process Innovation for Municipal WWTPs. Some innovated processes have been demonstrated to achieve good nutrients removal in China, such as (1) natural purification system, for example, various infiltrations and wetlands, (2) anaerobic biological treatment processes, for example, upflow anaerobic sludge blanket reactor, anaerobic filters, and anaerobic baffled reactor, (3) biofilm reactors, for example, three-phase fluidized reactor, and (4) wastewater reclamation techniques with the core of membrane separation $[8,13]$. 


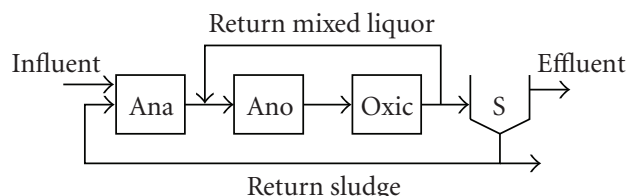

Conventional anaerobic-anoxic-oxic (AAO)

(a)

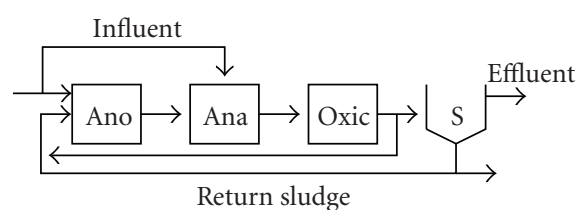

Reverse anaerobic-anoxic-oxic (r-AAO)

(b)

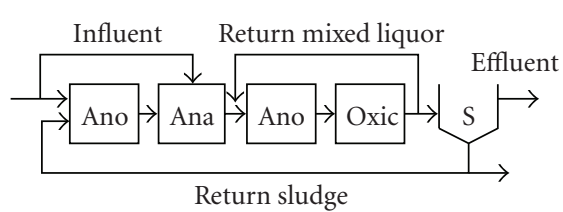

Pre anoxic anaerobic-anoxic-oxic (A-AAO)

(c)

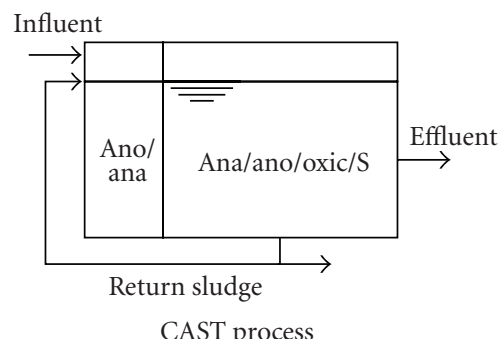

(e)

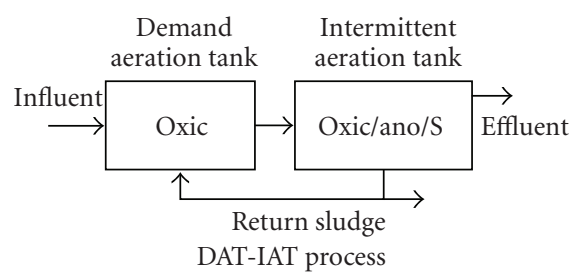

(g)

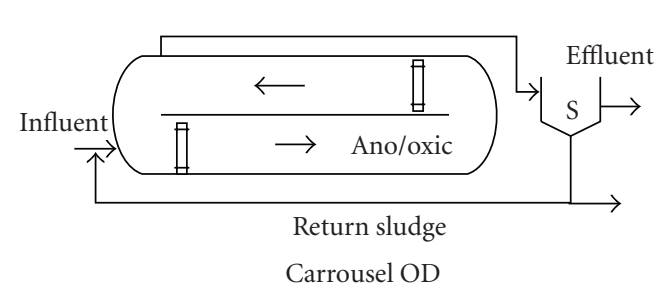

(i)

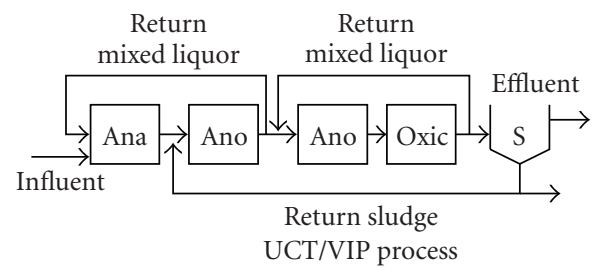

(d)

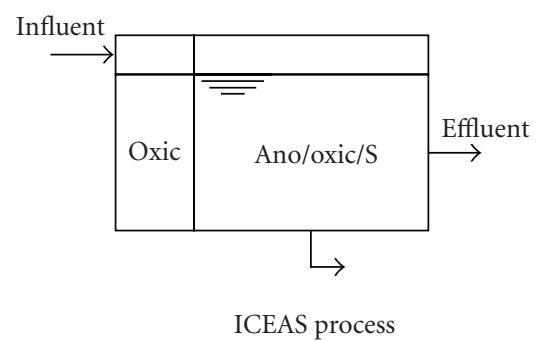

(f)

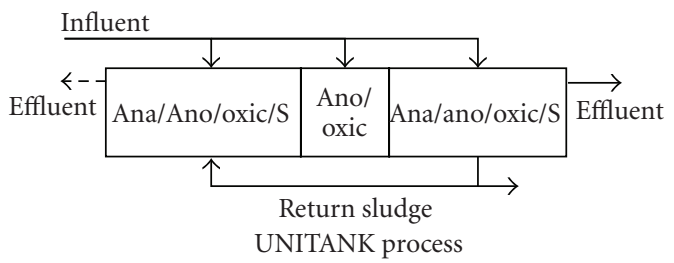

(h)

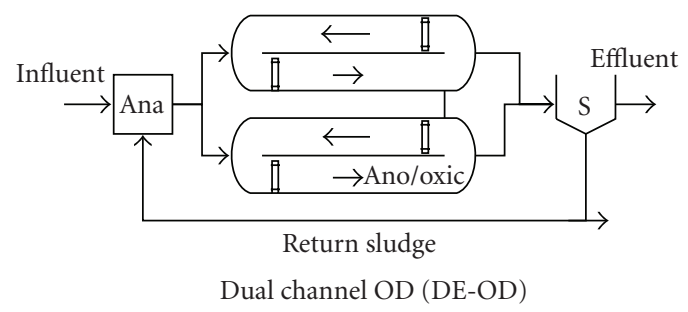

(j)

Figure 3: Continued. 


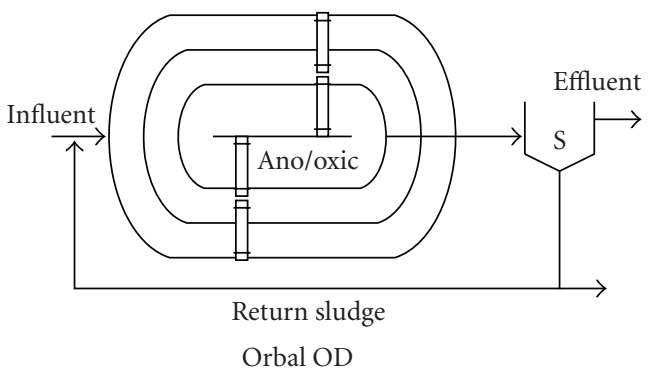

(k)

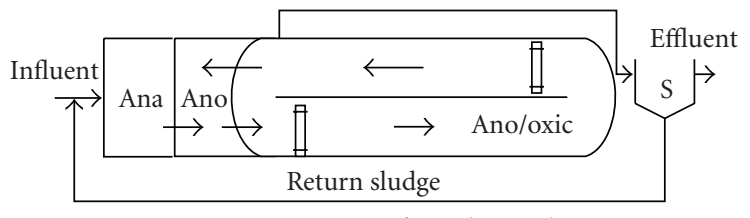

Pre-zone carrousel OD (A+OD)

(m)

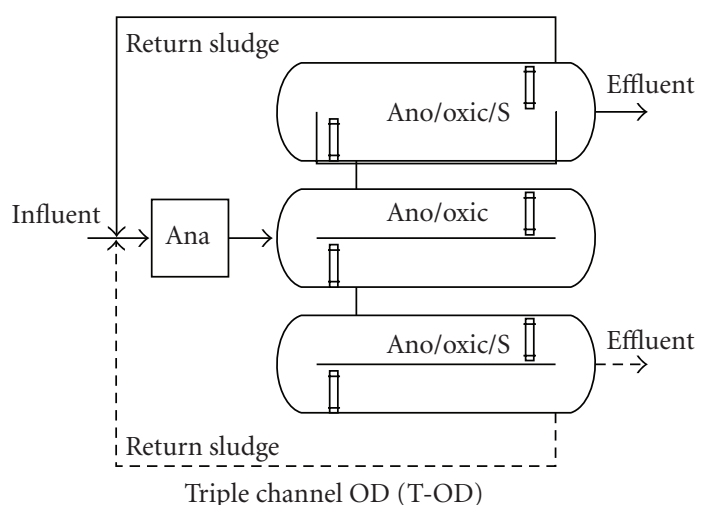

(1)

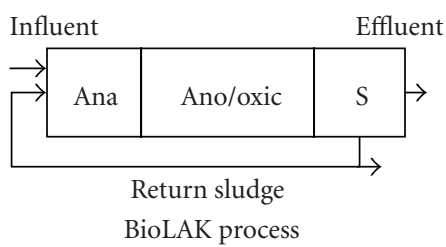

(n)

FIgURE 3: Scheme diagrams of major processes in WWTPs in China.

3.2.1. Innovation for Critic Environmental Conditions. Municipal wastewater treatment encountered some critic conditions such as high salinity in coasts, and frozen temperature in chilly zones. An integrated process (SANI, see Figure 4) consisting of sulfate reduction, autotrophic denitrification and nitrification was developed in Hongkong and applied in coastal areas of China to reclaim saline water without any excessive sludge discharge [14]. SBR was found also capable of removing nitrogen in saline wastewater by short-cut nitrification [15]. In chilly seasons, an internal circulation compound bioreactor worked well by isolation and immobilization of cold-adapted microorganisms onto soft polyurethane foams, with COD removal of $86 \%$ in the conditions of $4-10^{\circ} \mathrm{C}[16]$.

3.2.2. Innovation for Low Concentration Wastewater Treatment. The TN removal was often limited by the low concentrations of influent organics in South China. There were several techniques developed to deal with the lack of carbon sources, for example, a primary treatment process enhanced by composite flocculant which combined bioflocculants Pullulan and poly-aluminum-chloride (PAC) could achieve $91 \%$ and $15 \%$ of $\mathrm{TP}$ and $\mathrm{NH}_{3}-\mathrm{N}$ removal, respectively [17]. Biological contact oxidation process and biological aerated filter (BAF) process were also capable to enhance the nutrients removal by careful selection of the media [18]. The limited carbon source could be effectively utilized by optimized feeding methods, for example, four-stage stepfeeding AO process [19]. Another option was to utilize short-chain fatty acids generated during waste activated sludge fermentation in alkaline conditions as internal carbon sources [20].
3.2.3. Innovation for Lower Cost and Energy Consumption. Some techniques were innovated or optimized to save the land use and investments. Anaerobic-anoxic-nitrification (A2N, see Figure 4) process with two stages of return sludge flow utilizes denitrifying phosphorous removing bacteria (DPB) to removal nitrate and phosphorous simultaneously [21], which is more promising than UCT/VIP processes (see Figure 3) [22]. By simple modification of the flow lines, the DPB could be isolated and accumulated in the system to achieve better performance of denitrification [23]. Simultaneous nitrification and denitrification (SND) process via nitrite could obviously reduce the aeration and thus save the energy consumption, which could be achieved in SBR [15] and hybrid SBR systems [24]. The airlift oxidation ditch (AOD, see Figure 4), using underwater aeration to achieve simultaneous aeration and agitation, was operated in lower cost and higher efficiency than other oxidation ditches. The land use and energy consumption could be saved for $25 \%$ and $55 \%$, respectively, according to the pilot-scale experiments [25]. After integrating a transverse flow membrane module and a MBR in an innovative configuration, the system gained the advantages of lower energy consumption and more resistance to membrane fouling [26].

\section{Advances in Process Optimization}

Nutrients removal was often harmed by inadequate denitrification, inhibition of phosphorous removal by nitrate, over aeration, over dosage of chemicals, and improper operation of settling pretreatment tanks. In the last decade, attempts from both academic and engineering sides in China were contributed to improve the process operation in municipal WWTPs. 


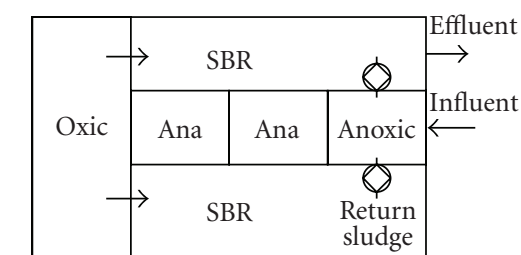

CSBR: continuous flow constant level SBR

(a)

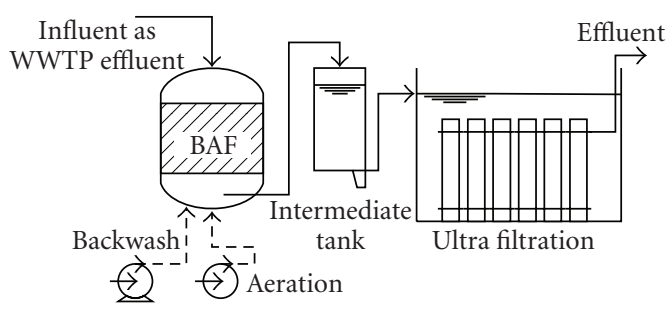

Dual filtration membrane bioreactor (DF-MBR)

(b)

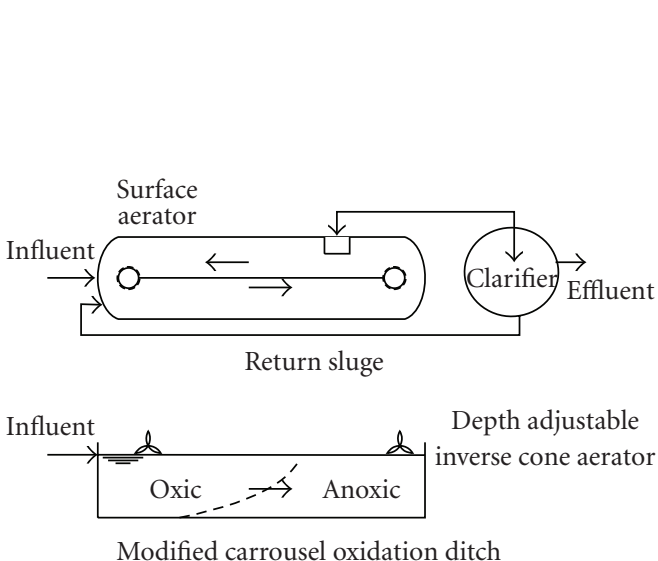

(c)

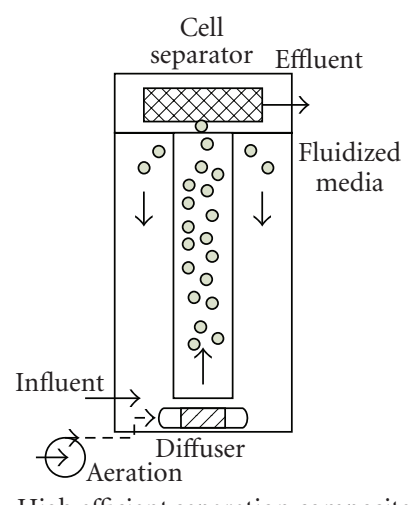

High efficient separation composite biological fluidized reactor (HSCBR)

(d)

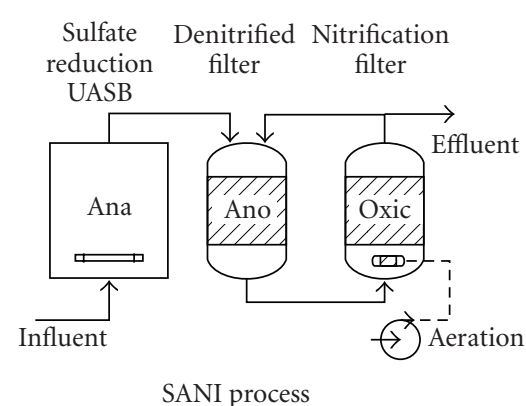

(e)

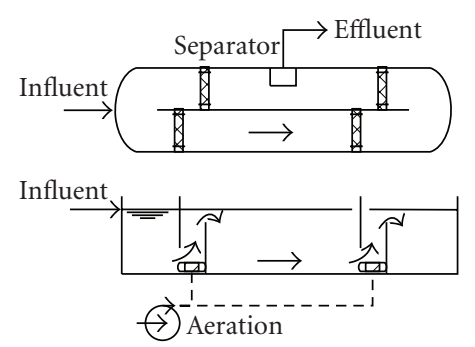

Airlift oxidation ditch (AOD)

(f)

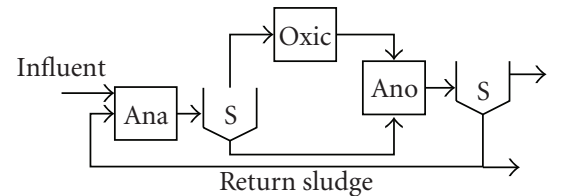

Anaerobic-anoxic-nitrification (A2N)

(g)

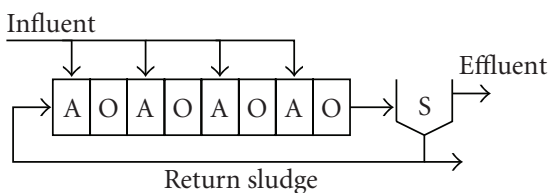

Four stage step feeding AO process

(h)

FIgURE 4: Innovated or modified processes in WWTPs in China.

4.1. Modeling, Simulation, and Optimization of Process. Modeling and simulation based on activated sludge models (ASMs) were useful to screen optimization strategies for process operation by an effective and economic method. The manipulative variables in actual AAO process, such as dissolve oxygen (DO), volumetric portions for denitrification, return flow rates, and excessive sludge flow rate, could be refined by the systematic procedure of modeling, simulation, and optimization [4]. Benchmarking simulation models (BSMs) were intensively studied for real-time control in last decades in China, helping to accumulate knowledge and testify the novel control methods like model predictive control strategies and sophisticated feedback control systems [27]. 
New models based on ASMs were developed in China for scientific studies and engineering feasibility. An integral model named fully coupled activated sludge model (FCASM) described the interactions of eight functional microorganisms involved in BNR processes [28], while a simplified model based on carbon oxidation steps in ASM1 was successfully applied in Jizhuangzi WWTP at Tianjing City [29].

Sedimentation tanks play important role for guarding the effluent with good quality. By using computational fluid dynamics (CFDs), the distribution of suspended solids in secondary sedimentation tanks could be simulated by the three-dimensional two-fluid model, resulting in useful information for process design [30]. Particle image velocimeter was useful to study the settling of activated sludge flocs under turbulent flow conditions, indicating that the settling velocity was correlated to the particle size, turbulence intensity, and solid concentrations [31]. Whatever, conventional models, such as Vesilind model and double exponential model, were still feasible for simulation of compression settling process by careful model calibration [32].

CFD technique was systematically applied in the field simulation, optimization of aerators and shapes of oxidation ditches. Particle dynamic analyzer (PDA) and CFD simulation were found useful to optimize the designs of Carrousel OD [33]. Nitrogen removal could be improved in Carrousel OD by controlling the return sludge flow, dissolved oxygen (DO), and influent sites according to the influent loadings and temperature [34]. The promotion of DO distribution to nitrogen removal was also observed in a fluidized bed reactor, which was affected by the vertical stratification of active sludge populations [35].

4.2. Real-Time Controlling for BNR Process. Operational optimization of process requires high levels of ICA techniques in municipal WWTPs. Unfortunately, the studies of real-time controlling system and relative strategies were very few in China, and mainly focused on SBR systems. In SBR process, even single variant control by DO level could achieve better biological nitrogen removal and sludge population optimization [36]. The control strategies utilized $\mathrm{pH}$ and oxidation reduction potential (ORP) as on-line control parameters could remove TN as high as 98\% with very low influent carbon/nitrogen ratio ( $\mathrm{C}: \mathrm{N}=3.5)$ [37]. By a real-time aeration control strategy based on $\mathrm{DO}$, $\mathrm{pH}$, and ORP, the short-cut nitrogen removal could be achieved by nitrification and denitrification via nitrite [38]. Furthermore, the performance and benefits of the real-time controlling system were validated in a pilot-scale SBR [39]. Fuzzy control strategies were applied in scientific studies for the real-time control of activated sludge process. For example, AO process could be optimized by using on-line sensors $\mathrm{DO}, \mathrm{pH}$, and ORP and fuzzy inference system to control aeration, nitrate recirculation flow, and external carbon dosage [40].

4.3. Implementation of ICA Techniques. Although current ICA techniques are in state-of-art, application of ICA in municipal WWTPs in China was obstructed by the expensive instruments and controllers, rare and ineffective maintenance, easily broken actuators, lack of knowledge, and absence of consultancies. Although automatic control was utilized in most of SBR systems, it was limited in unit operations instead of process optimal operation. The first application of feed-forward control by ICA techniques, in its original meaning, might be the reformation project of Bailonggang WWTP in Shanghai City in 2008, in which a bioprocess intelligent optimization system (BIOS, BioChem Company, USA) [41] was installed to control the aeration based on the online signals of ammonia and nitrate.

\section{Future Perspectives}

The appropriated processes or technologies for municipal WWTPs in China have the features of high efficiency and stability, lower energy consumption and operational cost, easy operation and maintenance, and lower specific footprint to reduce the occupied land area and the investment [13]. Additionally, suitable technologies for wastewater handling in small communities were necessary for the purpose of scattering treatment instead of centralizing sewer systems [42].

Although a lot of attempts have been contributed for nutrients removal, more attentions should be paid to the introduction, instruction, and implementation of advanced techniques in municipal WWTPs by considering the urgent crisis of surface water contamination and water resource shortage. The Major Projects on Control and Rectification of Water Body Pollution (2005-2020), which are supported by the central and local governments and enterprises, has covered the most topics of municipal wastewater treatment and will greatly promote the development and application of new techniques.

\section{Conclusions}

This paper reviewed the advances of nitrogen and phosphorous removal in municipal WWTPs in China. The construction of municipal WWTPs was gradually increased in last decade. AAO, SBR, and OD processes were major candidates for process design, but their performances were unsatisfied according to the more strict discharge criteria. Typical problems in process design and operation were summarized as inadequate knowledge of influent, design defect, and undeveloped ICA techniques. Great efforts had been made by researchers and industries to deal with the problems, including process design innovated for critic conditions, low concentration of influents, and saving energy consumption, and process optimization achieved by modeling and simulation, real-time control, and implementation of ICA techniques. Despite of all those efforts, more attentions should be paid to the implementation of advanced techniques in municipal WWTPs. Finally, the appropriate techniques and future perspectives were briefly discussed. 


\section{Nomenclature}

AAO: $\quad$ Anaerobic-anoxic-oxic process

A-AAO: $\quad$ AAO process with preanoxic zone

AO: $\quad$ Anoxic-oxic or anaerobic-oxic process

CAS: Conventional activated sludge process

ASMs: $\quad$ Activated sludge models

A+OD: $\quad$ Carrousel-OD with preanaerobic zones

BAF: Biological aeration filter

BNR: Biological nutrient removal process

BSMs: Benchmarking simulation models

Carrousel-OD: Carrousel type oxidation ditch

CAST: $\quad$ Cyclic activated sludge technology, a

type of SBR

CFD: $\quad$ Computational fluid dynamics

COD: Chemical oxygen demand

DAT-IAT: Demand aeration tank and intermittent aeration tank, a type of SBR

DE-OD: Dual channels oxidation ditch

DF-MBR: Dual filtration membrane bioreactor

DO:

DPB: Dissolved oxygen

HSCBR: Dionitrification phosphorous bacteria

biological fluidized reactor

ICA: Instrumentation, control and automation

ICEAS: Intermittent cycle extended aeration system, a type of SBR

$\mathrm{NH}_{3}-\mathrm{N}$ : Ammonia nitrogen

MBR: $\quad$ Membrane biological reactor

OD: Oxidation ditch process

Orbal-OD: Orbal type oxidation ditch

ORP:

PDA:

r-AAO:

SBR:

SND:

T-OD:

TP:

TN:

UASB:

Oxidation and reduction potential

Particle dynamic analyzer

Anoxic-anaerobic-oxic process

Sequencing batch reactor

Simultaneous nitrification and

denitrification

Triple channels oxidation ditch

Total phosphorous

Total nitrogen

$\begin{array}{ll} & \text { reactor } \\ \text { UCT/VIP: } & \text { University of Campton Tank/VIP }\end{array}$

UNITANK: A type of SBR

WWTP: Wastewater treatment plant.

\section{Acknowledgments}

This study was supported by a Key Project in the National Science \& Technology Pillar Program of China (2006BAC19B06) and one of the Major Projects on Control and Rectification of Water Body Pollution (2009ZX07313003).

\section{References}

[1] National Engineering Research Center for Urban Water and Wastewater, "The state and planning of municipal sewage treatment in China," in China Environmental Protection Industry, vol. 1, pp. 32-35, 2003.

[2] China Statistic Year Book on Environment 2001, 2002, 2003, 2004, 2005, 2006, 2007, China Statistic, 2002-2008.

[3] China association of Drainage and Water Supply. China wastewater treatment plants compilation. Publishing in Beijing.

[4] L. $\mathrm{Xu}$ and H. Shi, "Introduction and application of the operation decision support system for wastewater treatment plants (WWTP ODSS)," Water and Wastewater, vol. 32, pp. 105-108, 2006 (Chinese).

[5] N. Li, X. Wang, N. Ren, K. Zhang, and H. Kang, "Application of nitrogen and phosphorous removal processes in wastewater treatment plants in China," Water and Wastewater, vol. 34, pp. 39-42, 2008 (Chinese).

[6] J. Fan, T. Tao, J. Zhang, and G.-L. You, "Performance evaluation of a modified anaerobic/anoxic/oxic (A2/O) process treating low strength wastewater," Desalination, vol. 249, no. 2, pp. 822-827, 2009.

[7] G. Zeng, R. Jiang, G. Huang, M. Xu, and J. Li, “Optimization of wastewater treatment alternative selection by hierarchy grey relational analysis," Journal of Environmental Management, vol. 82, no. 2, pp. 250-259, 2007.

[8] Committee of Water Pollution Treatment, "Technical Development Report on Water Pollution Treatment Industry of Our Country in 2007," China Environmental Protection Industry, vol. 11, pp. 12-16, 2008.

[9] G.-F. He, Z.-Y. Zhou, and T.-Y. Gao, "Denitrification effect and affecting factors of activated sludge process with addition of suspended carrier," China Water and Wastewater, vol. 19, no. 6, p. 6, 2003 (Chinese).

[10] J. Wang, H. Shi, and Y. Qian, "Wastewater treatment in a hybrid biological reactor (HBR): effect of organic loading rates," Process Biochemistry, vol. 36, no. 4, pp. 297-303, 2000.

[11] J. Guo, F. Ma, C.-C. Chang et al., "Start-up of a two-stage bioaugmented anoxic-oxic (A/O) biofilm process treating petrochemical wastewater under different DO concentrations," Bioresource Technology, vol. 100, no. 14, pp. 3483-3488, 2009.

[12] Z. Wu, Y. An, Z. Wang et al., "Study on zeolite enhanced contact-adsorption regeneration-stabilization process for nitrogen removal," Journal of Hazardous Materials, vol. 156, no. 1-3, pp. 317-326, 2008.

[13] Y. Qian, X. Wen, and X. Huang, "Development and application of some renovated technologies for municipal wastewater treatment in China," Frontiers of Environmental Science and Engineering in China, vol. 1, no. 1, pp. 1-12, 2007.

[14] H. Lu, J. Wang, S. Li, G.-H. Chen, M. C. M. van Loosdrecht, and G. A. Ekama, "Steady-state model-based evaluation of sulfate reduction, autotrophic denitrification and nitrification integrated (SANI) process," Water Research, vol. 43, no. 14, pp. 3613-3621, 2009.

[15] L. Ye, C.-Y. Peng, B. Tang, S.-Y. Wang, K.-F. Zhao, and Y.-Z. Peng, "Determination effect of influent salinity and inhibition time on partial nitrification in a sequencing batch reactor treating saline sewage," Desalination, vol. 246, no. 1-3, pp. 556-566, 2009.

[16] Y. Ben, Z. Chen, Z. Xu, and A. Jiang, "Application of immobilized psychrotrophs in ICCBR to treat domestic wastewater and its microbiological investigation," Chinese Science Bulletin, vol. 54, no. 9, pp. 1599-1606, 2009.

[17] K. Yang, X.-J. Yang, and M. Yang, "Enhanced primary treatment of low-concentration municipal wastewater by means 
of bio-flocculant Pullulan," Journal of Zhejiang UniversityScience A, vol. 8, no. 5, pp. 719-723, 2007.

[18] G. Qiu, L. Xiang, Y. Song, J. Peng, P. Zeng, and P. Yuan, "Comparison and modeling of two biofilm processes applied to decentralized wastewater treatment," Frontiers of Environmental Science and Engineering in China, pp. 1-9, 2009.

[19] G. Zhu, Y. Peng, L. Zhai, Y. Wang, and S. Wang, "Performance and optimization of biological nitrogen removal process enhanced by anoxic/oxic step feeding," Biochemical Engineering Journal, vol. 43, no. 3, pp. 280-287, 2009.

[20] J. Tong and Y. Chen, "Recovery of nitrogen and phosphorus from alkaline fermentation liquid of waste activated sludge and application of the fermentation liquid to promote biological municipal wastewater treatment," Water Research, vol. 43, no. 12, pp. 2969-2976, 2009.

[21] T. Kuba, M. C. M. van Loosdrecht, and J. J. Heijnen, "Phosphorus and nitrogen removal with minimal COD requirement by integration of denitrifying dephosphatation and nitrification in a two-sludge system," Water Research, vol. 30, no. 7, pp. 1702-1710, 1996.

[22] X. Hao, M. C. M. van Loosdrecht, S. C. F. Meijer, and Y. Qian, "Model-based evaluation of two BNR processes-UCT and A2N," Water Research, vol. 35, no. 12, pp. 2851-2860, 2001.

[23] H. Liu, L. Sun, and S. Xia, "An efficient DPB utilization process: the modified A2N process," Biochemical Engineering Journal, vol. 38, no. 2, pp. 158-163, 2008.

[24] J. Wang, Y. Peng, S. Wang, and Y. Gao, "Nitrogen removal by simultaneous nitrification and denitrification via nitrite in a sequence hybrid biological reactor," Chinese Journal of Chemical Engineering, vol. 16, no. 5, pp. 778-784, 2008 (Chinese).

[25] H. Pang, H. Shi, and H. Shi, "Flow characteristic and wastewater treatment performance of a pilot-scale airlift oxidation ditch," Frontiers of Environmental Science and Engineering in China, vol. 3, no. 4, pp. 470-476, 2009.

[26] S. Zhang, R. van Houten, D. H. Eikelboom et al., "Sewage treatment by a low energy membrane bioreactor," Bioresource Technology, vol. 90, no. 2, pp. 185-192, 2003.

[27] W. Shen, X. Chen, M. N. Pons, and J. P. Corriou, "Model predictive control for wastewater treatment process with feedforward compensation," Chemical Engineering Journal, vol. 155, no. 1-2, pp. 161-174, 2009.

[28] P. Sun, R. Wang, and Z. Fang, "Fully coupled activated sludge model (FCASM): model development," Bioresource Technology, vol. 100, no. 20, pp. 4632-4641, 2009.

[29] M. Ji, J. S. Huo, Z. L. Hu, W. J. Ma, W. Y. Liu, and B. X. Zhang, "Study and application of mathematical model for activated sludge process," China Water \& Wastewater, vol. 17, no. 8, pp. 18-22, 2001 (Chinese).

[30] L. Fan, N. Xu, X. Ke, and H. Shi, "Numerical simulation of secondary sedimentation tank for urban wastewater," Journal of the Chinese Institute of Chemical Engineers, vol. 38, no. 5-6, pp. 425-433, 2007.

[31] L. Guo, D. Zhang, D. Xu, and Y. Chen, "An experimental study of low concentration sludge settling velocity under turbulent condition," Water Research, vol. 43, no. 9, pp. 2383-2390, 2009.

[32] D. Zhang, Z. Li, P. Lu, T. Zhang, and D. Xu, "A method for characterizing the complete settling process of activated sludge," Water Research, vol. 40, no. 14, pp. 2637-2644, 2006.

[33] L. Fan, N. Xu, Z. Wang, and H. Shi, "PDA experiments and CFD simulation of a lab-scale oxidation ditch with surface aerators," Chemical Engineering Research and Design, vol. 88, no. 1, pp. 23-33, 2010 (Chinese).
[34] Y. Liu, H. Shi, L. Xia et al., "Study of operational conditions of simultaneous nitrification and denitrification in a Carrousel oxidation ditch for domestic wastewater treatment," Bioresource Technology, vol. 101, no. 3, pp. 901-906, 2010.

[35] Q. Wen, Z. Chen, and H. Shi, "T-RFLP detection of nitrifying bacteria in a fluidized bed reactor of achieving simultaneous nitrification-denitrification," Chemosphere, vol. 71, no. 9, pp. 1683-1692, 2008.

[36] J. Guo, Y. Peng, S. Wang, Y. Zheng, H. Huang, and Z. Wang, "Long-term effect of dissolved oxygen on partial nitrification performance and microbial community structure," Bioresource Technology, vol. 100, no. 11, pp. 2796-2802, 2009.

[37] J. Guo, Q. Yang, Y. Peng, A. Yang, and S. Wang, "Biological nitrogen removal with real-time control using step-feed SBR technology," Enzyme and Microbial Technology, vol. 40, no. 6, pp. 1564-1569, 2007.

[38] C. Wu, Z. Chen, X. Liu, and Y. Peng, "Nitrification-denitrification via nitrite in SBR using real-time control strategy when treating domestic wastewater," Biochemical Engineering Journal, vol. 36, no. 2, pp. 87-92, 2007.

[39] Q. Yang, S. Wang, A. Yang, J. Guo, and F. Bo, "Advanced nitrogen removal using pilot-scale SBR with intelligent control system built on three layer network," Frontiers of Environmental Science and Engineering in China, vol. 1, no. 1, pp. 33-38, 2007.

[40] Y. Z. Peng, Y. Ma, and S. Y. Wang, "Improving nitrogen removal using on-line sensors in the A/O process," Biochemical Engineering Journal, vol. 31, no. 1, pp. 48-55, 2006.

[41] C. Huang, C. Zhang, and X. Wang, "Application of bioprocess intelligent optimization system in wastewater treatment plant," Electric Automation, vol. 28, pp. 71-73, 2006 (Chinese).

[42] G. O. Engin and I. Demir, "Cost analysis of alternative methods for wastewater handling in small communities," Journal of Environmental Management, vol. 79, no. 4, pp. 357363, 2006. 

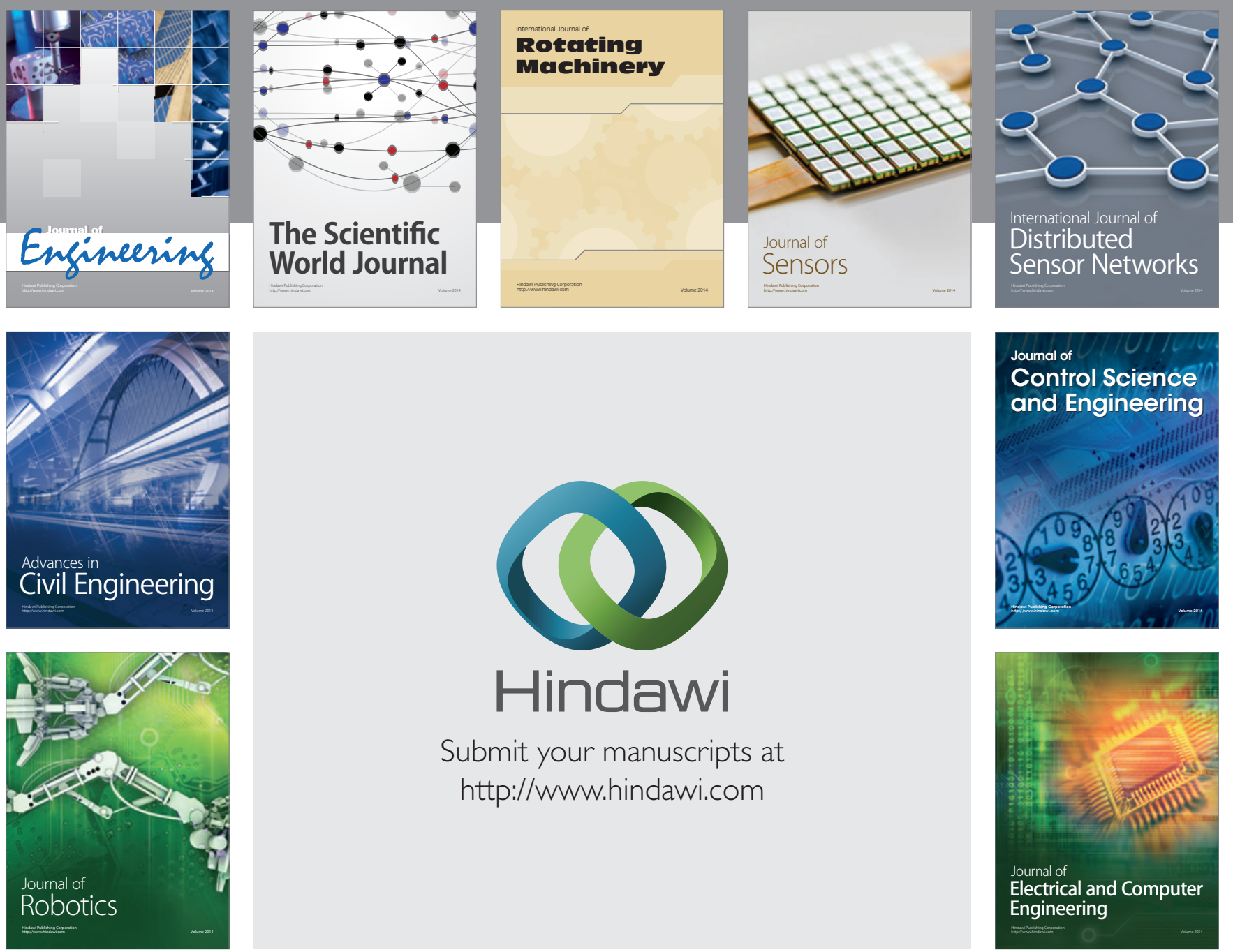

Submit your manuscripts at

http://www.hindawi.com
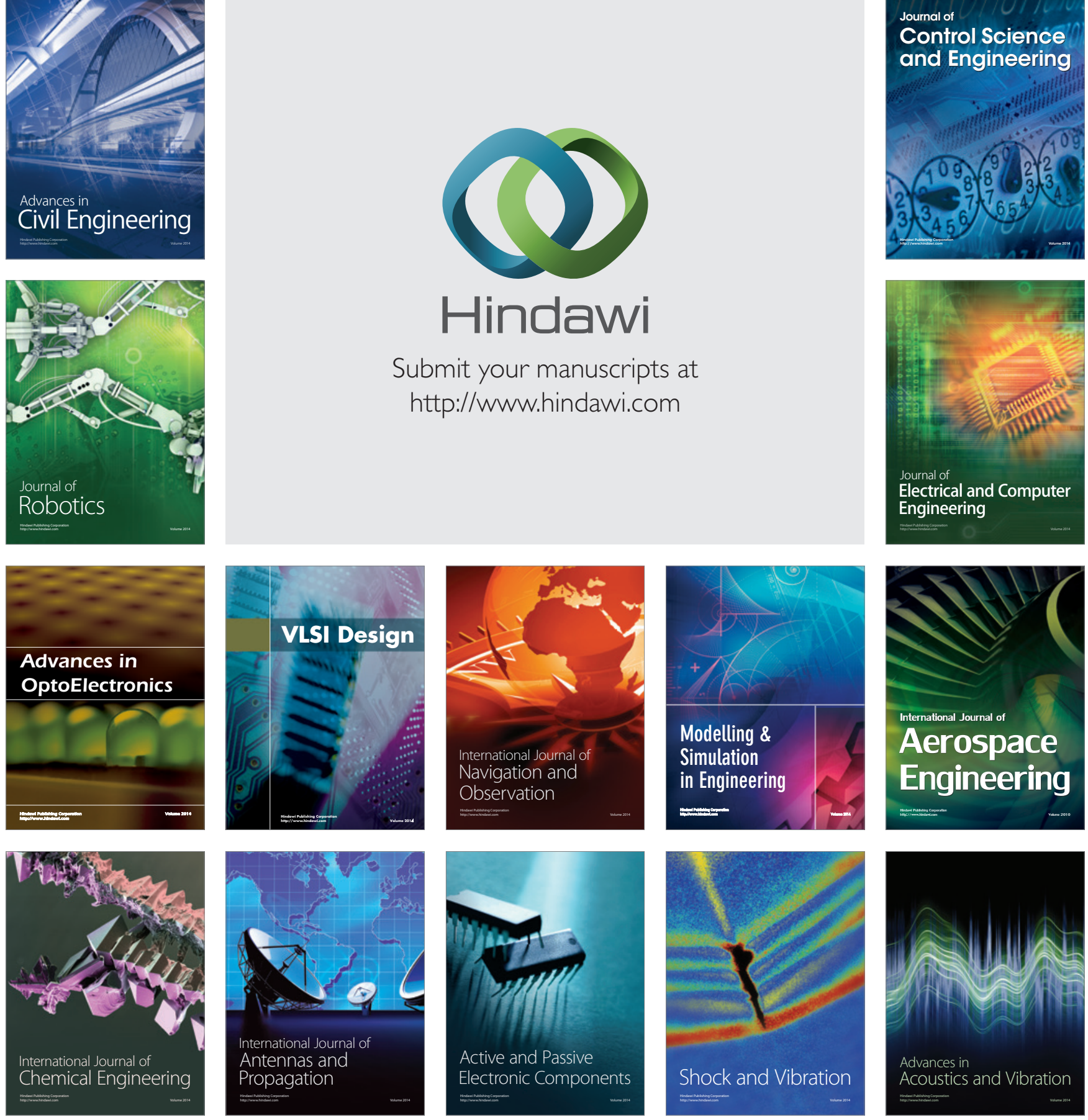